\title{
Contested EU trade governance: transparency conundrums in TTIP negotiations
}

\author{
Eugénia C. Heldt ${ }^{1}$
}

Published online: 1 April 2019

(c) The Author(s) 2019

\begin{abstract}
During TTIP negotiations, the European Commission was severely criticized by civil society organizations and public opinion for its secrecy regarding negotiation strategies and priorities. The Commission responded by making some negotiating texts publicly available. This article explores the implications of increasing transparency in trade negotiations. Drawing on negotiation, politicization, and informal governance literature, it examines how the Commission's choice for a partial transparency approach had three paradoxical effects on negotiations. First, greater transparency did not help the public perception of TTIP. Second, greater transparency increased the EU's bargaining leverage but led to a low degree of negotiating discretion for the Commission. Finally, greater transparency transformed the nature of the negotiating process by making it more informal, allowing bargaining parties to act outside the public scrutiny. This contribution solves these transparency puzzles by showing that partial transparency is a double-edged sword. Whilst greater transparency has become an important legitimation strategy in EU trade governance, adopting a partial transparency approach fuelled public protest instead of muting it and led to the failure of the negotiations.
\end{abstract}

Keywords TTIP · Trade negotiations · European Commission · Transparency · Contestation

\section{Introduction}

The Transatlantic Trade and Investment Partnership (TTIP) negotiations between the European Union (EU) and the USA led to an unprecedented level of contestation by civil society organizations (CSOs), the media, and members of the European Parliament (EP). In November 2014, the European trade commissioner, Cecilia

Eugénia C. Heldt

eugenia.heldt@hfp.tum.de

1 Hochschule für Politik München, TUM School of Governance, Technical University of Munich, Richard-Wagner-Straße 1, 80333 Munich, Germany 
Malmström, responded by increasing transparency in three different ways. First, the European Commission (henceforth, the Commission) established a civil society forum in which it reported back to civil society groups after each trade round. ${ }^{1}$ Second, the Commission made a large majority of negotiating texts available on its website. Third, the Commission established a new unit entitled "Transparency, Communication, and Civil Society" to enhance societal dialogue, transparency, and accountability. However, these measures did not diminish protests against TTIP. On the contrary, increased transparency was accompanied by further mobilization by CSOs. In fall 2015, discontent culminated in an anti-TTIP demonstration in Berlin that assembled some 200,000 participants-in a country that would have been the major beneficiary of further trade liberalization between the two trade powers.

Against this background, this article explores the implications of greater transparency in trade negotiations. We argue that the Commission, by adopting a partial transparency approach, involving the public disclosure of some negotiating texts, provoked three marked-and paradoxical—consequences for TTIP negotiations. First, greater transparency unexpectedly enhanced contestation instead of quieting it down. This is puzzling, as the international relations literature shows that greater transparency in decision-making has become an important legitimation strategy of international organizations for decreasing politicization (Gronau and Schmidtke 2016; Tallberg et al. 2013). Second, increasing transparency has strengthened the EU's bargaining leverage vis-à-vis the USA, but has reduced the negotiating discretion of the Commission. By discretion we mean the leeway conferred on the Commission to accomplish a negotiating mandate. From a negotiation analysis perspective, increasing transparency is also puzzling, as negotiating power usually requires secrecy and disclosing information can lead to either an increase or decrease in EU bargaining leverage (Raiffa et al. 2002; Stasavage 2004). Third, the decision to increase transparency had the paradoxical effect of shifting decision-making processes to informal networks and practices, giving both sides more flexibility to act outside public scrutiny, but engendering more contestation.

The key to these transparency conundrums is that transparency is a double-edged sword. In times of public contestation and protest, partially increasing transparency might initially seem an attractive legitimation strategy. It allows the Commission to stay in charge of what information is released and can be expected to pacify public protest. The result, however, might be different because partial information reveals to the public that certain information is still classified. This might unexpectedly lead to an increase in contestation because partial transparency augments the sense of secrecy instead of silencing it. Only a strategy of full transparency, understood as the public disclosure of all negotiating texts by the two negotiating parties, can mitigate contestation. At the same time, the partial publication of negotiating texts can have

\footnotetext{
1 To be sure, civil society dialogues have always been part of the Commission's communication strategy. Examples include the "Trade Dialogue with Civil Society" launched in 1998, the 2002 "Transatlantic Guidelines on Regulatory Cooperation and Transparency", the 2005 "European Transparency Initiative", the 2011 "Transparency Register", and the 2012 "Transparency Portal". For a discussion of how the Commission used transparency to increase its legitimacy, see Meunier (2003).
} 
a twofold effect on the Commission's bargaining leverage. First, it might decrease EU bargaining leverage should the other side insist on greater concessions. Second, partial transparency can have exactly the opposite effect. Rather than decreasing EU bargaining leverage, it might increase it. The paradox of internal weakness (Schelling 1960) can be a source of bargaining power, as the Commission can point to recalcitrant EU member states to extract more concessions from the other side. Finally, greater transparency can, paradoxically, lead to the informalization of trade negotiations. Discussions outside formal institutional channels might help to make negotiations less visible to the public and might help level the playing field among negotiation partners. Drawing on the informal governance literature, we show that informalizing EU trade governance might also exacerbate rather than mitigate public contestation.

The analysis draws on two sets of empirical data: first, primary sources, including documents and minutes - from the Council of Ministers (henceforth, the Council), the Commission, and the EP-on the negotiations between the EU and the USA from 2013 to 2016; and second, semi-structured interviews with officials from the Commission's Directorate General (DG) for Trade, Council officials from DG Trade, and officials from the Trade Policy Committee (TPC). ${ }^{2}$ The highly complex and technical TTIP negotiations involved 150 officials in 24 negotiating groups spanning market access, regulatory issues and non-tariff barriers, trade-related rules, and investment protection (Council of the European Union 2014). Although negotiations came to a standstill in September 2016, when a series of member states consecutively pulled the plug (Euractiv 2 September, 2016), TTIP remains a case in point to examine how increasing transparency did not help public perception of a trade agreement between two trade powers but rather diminished public acceptance.

This article proceeds in four steps. Section two reviews the present literature on TTIP negotiations, transparency, and contestation, theorizes the effect of greater transparency on TTIP negotiations, and derives a set of propositions. The third section probes these propositions and presents three paradoxical findings. The conclusion summarizes results and outlines the consequences of these developments.

\section{Contestation, bargaining leverage, and informalization}

Despite increased theoretical and empirical attention to EU trade policy and TTIP, fewer studies have directly examined how transparency shapes EU trade governance. Studies analysing the politics of transatlantic trade negotiations focus on their theoretical and historical context; negotiations, actors, and agencies; knock-on effects and unintended consequences for third-parties; implications for multilateral

\footnotetext{
2 The interviews took place from 11 to 14 January 2016 in Brussels. I am particularly grateful to the following officials from the European Commission's Directorate General Trade, Council officials from the General Direction Trade, Development, Horizontal Issues and Foreign Affairs and from TPC for their availability and willingness to share their knowledge with me: John Clarke, Luca De Carli, Ignacio Garcia-Bercero, Lutz Güllner, Bostja Krasovec, Alda Silveira Reis, and Ruta Zarnauskaite. None of the opinions expressed in the interviews are attributed to a particular person. All interviews are therefore cited in chronological number.
} 
institutions and regime complexes (see the contributions in Morin et al. 2015); transatlantic partnerships (Teló 2015); and whether or not TTIP is a game-changer (De Bièvre and Poletti 2016; De Ville and Siles-Brügge 2016; Eliasson and GarcíaDuran 2016). Other scholars have examined the distinctiveness of TTIP negotiations (De Ville and Siles-Brügge 2016; Smith 2015; Young 2016), the role of the EU and USA as rule-makers and takers (Hamilton and Pelkmans 2015), competitive interdependence (Damro 2015), and the importance of legislative-executive relations (Jančić 2017). ${ }^{3}$ Young (2017), in turn, argues that efforts to deepen integration have been pivotal to the politicization of trade policy. A new wave of studies on transparency and contestation predominantly draws our attention to the role played by CSOs during TTIP negotiations. Whilst Bauer (2016) has argued that the use of social media has facilitated CSO influence, other scholars (De Ville and SilesBrügge 2016; Young 2016) underline the unprecedented focus of their campaigns on non-tariff barriers. For example, Siles-Brügge (2017) stresses the importance of emotions in advocacy framing related to the issue of transatlantic investor protection, arguing that CSOs created a polysemic "injustice frame". Others contend that the broader and deep the regulatory agenda of a trade agreement is, the more likely political mobilization by CSOs (Eliasson and García-Duran 2016) will be. Other studies focus on the Investor-State Dispute System, the export of US-produced GMOs to the EU, and the inclusion of public services in TTIP (Aggarwal and Evenett 2016) to explain the increased contestation of TTIP. Huet and Elliasson (2017) identify the rhetorical strategies of TTIP proponents, namely EU trade commissioners from 2013 to 2016, in response to contestation over TTIP. Other studies on transparency and contestation examine how the Commission moved from a reactive strategy of providing transparency based on access to documents to the proactive provision of information (Coremans 2017) or how a combination of CSO contestation campaigns against TTIP, allied with consensus decision-making in the Council, led to a low degree of negotiating autonomy for the Commission and increased EU bargaining power (De Bièvre 2018). Gheyle and De Ville (2017) show that several transparency measures undertaken by the Commission did not silence contestation, as CSOs asked for full transparency for and participation by CSOs. This contribution complements the literature in three ways. First, it examines how the Commission's strategy of increasing transparency had different, paradoxical effects on TTIP negotiations. Second, it relies on extensive interviews with involved actors. Third, it brings together different strands of literature, negotiation analysis, politicization, and informal governance literature.

\footnotetext{
${ }^{3}$ Recently, Dür (2017) has published a virtual special issue on trade in which he divides EU trade policy literature into an external side and internal side. These include the articles by Meunier and Nicolaidis (2006) on the EU as a conflicted trade power, Conceição-Heldt (2014) on bargaining power (a)symmetry and EU external effectiveness as well as Young's (2015) piece on the limits to regulatory co-ordination in the EU's new generation of preferential trade agreements.
} 


\section{Transparency and contestation}

Contested multilateralism (Morse and Keohane 2014) is now a central feature of global governance. Protest and criticism of European and global governance has been linked to the lack of transparency and democratic control (Grigorescu 2015; Tallberg 2016). Studies on the politicization of European integration-defined as the public contestation of the authority of supranational institutions-consider that contestation has been characterized not only by "a patchwork of politicizing moments" (Hutter et al. 2016) but has also been embedded in national political conflict structures that vary between European regions (Kriesi 2016). Hooghe and Marks (2009) examine the turn "from permissive consensus to constraining dissensus" by focusing on the politicization of European integration in elections and referendums. As a result, the preferences of the general public and of national political parties have become decisive for outcomes in shaping contestation on Europe. The postfunctionalist perspective expects politicization to mobilize Euro-sceptic citizens around national identities, empower anti-European parties, and undermine support for the European integration project. International relations and EU studies focusing on the consequences of politicization (Kriesi 2016) demonstrate that international and supranational institutions react to criticism by increasing transparency, for example, by providing public information about their activities. Thus, greater transparency has become an important legitimation strategy in European and global governance (Gronau and Schmidtke 2016). To our best knowledge, however, the literature tells us little about the implications of increasing transparency for EU governance in terms of helping pacifying public protest, increasing or decreasing EU bargaining leverage, and in establishing new governance practices.

In this contribution, we use the term transparency to denote public access to information about the Commission's activities and positions on trade negotiations (see also Tallberg 2016; Gheyle and De Ville 2017). We argue that low transparency, ${ }^{4}$ meaning that parties negotiate secretly and the public has access only to general information about negotiations, is problematic, as it is likely to increase contestation if the public salience of an issue is high. Releasing information to the public about negotiations is a rational strategy for both sides to minimize the contestation of TTIP and thus increase the acceptance of policy outcomes (see also Stasavage 2004; Meunier 2005). If there is contestation of trade governance in a situation of low degree of transparency, European institutions and other involved parties have

\footnotetext{
${ }^{4}$ The International Relations literature uses three different transparency concepts: transparency-as-disclosure, transparency-as-dialogue, and transparency-as-information (McCarthy and Fluck 2016). Transparency-as-disclosure refers to the perceived legitimacy and accountability of governing institutions and carries a positive normative value. Transparency-as-dialogue is linked to an ethical orientation towards others. Closely linked to social constructivist approaches and Habermas' (1995) theory of communicative action, transparency-as-dialogue focuses on "mutual openness about reasons and motivations in a continual process of rational communication" (McCarthy and Fluck 2016: 7). Finally, transparency-asinformation is conceptualized as the disclosure of information between states. Tallberg (2016) distinguishes between transparency to refer to public access to information about the activities and policies of IOs and openness which is concerned with non-state actor access to IO policy-making. In this piece, the focus is merely on transparency-as-disclosure of information.
} 
the choice between: (a) not reacting at all and standing the storm; (b) providing partial transparency; (c) shifting to a strategy of full transparency. These three strategies correspond to what we label three degrees of transparency: low, partial and full.

A low degree of transparency means that parties negotiate secretly and the public has access only to general information about negotiations. This can occur in the form of press conferences in which both sides inform the public about the issues at stake without disclosing the negotiating texts. Bargaining requires a certain degree of insulation, and international negotiations are usually not particularly transparent (Stasavage 2004). A low degree of transparency has the advantage of permitting parties to negotiate without public pressure and to disclose details only at the ratification stage. However, it can increase contestation because the public is not informed on the state of negotiations. This might raise concerns about the secrecy and limited accountability of supranational institutions. Partial transparency can similarly fuel contestation instead of muting it.

Partial transparency means that the public is given partial access to information during the negotiation process and at the ratification stage. Access to information can take place in the form of press conferences, the disclosure of negotiating positions of both negotiating parties, and texts on websites, or by providing stakeholders and citizens with detailed information on the state of play (see also McCarthy and Fluck 2016; Coremans 2017). Opting for partial transparency can appear attractive to bargaining parties, giving them the power to decide the scope of the information released. This might, however, backfire, because partial information reveals that some information is still undisclosed and there are some secret texts both sides are hiding from the public. This can unintentionally step up rather than abate contestation (for a similar argument, see also Czesana and Meunier 2018). Both low and partial transparencies are more likely to lead to greater contestation than full transparency, as stakeholders can worry that some issues remain secret.

Finally, full transparency exists when all relevant negotiating texts are made public by the two negotiating partners. The choice of a full transparency approach by both sides is more likely to invalidate protester arguments about secrecy and lack of accountability. The degree of transparency in negotiations is a function of both sides' strategies over access to documents. This means, in turn, that an EU decision to provide full access to all relevant documents does not suffice to generate full transparency. Only when both sides, the EU and the USA, disclose all relevant information does full transparency obtain. Gheyle and De Ville (2017) find that the contestation of TTIP negotiations could not be silenced because of the disparity between what CSOs demanded and what the Commission provided. Whilst CSO "transparency demands" included full transparency for and participation of CSOs, this was never really a priority of the Commission, which instead established a small Advisory Group of representatives giving voice to, for instance, CSOs and business and trade union representatives.

Once contestation has arisen, the only way to diminish mistrust among the public on the secrecy of negotiations is to make all negotiating texts from both negotiating partners available to the public. This strategy of full transparency might help decrease politicization and weaken protesters' arguments about secrecy and a lack of accountability. This brings us to the first proposition: 
Low and partial transparency does not help public perception and might lead to more contestation because partial access to information reveals to the public that part of the negotiating texts is still classified.

\section{Effects of transparency on bargaining leverage}

Negotiation theorists postulate that, in order to obtain the best possible outcome of negotiations, actors should not reveal their true position at the beginning of negotiations (Lax and Sebenius 1986; Raiffa et al. 2002). Negotiations require secrecy, expertise, and flexibility. It is part of the negotiating game to start negotiations with extreme or maximalist demands and to withhold the true reservation line from one's negotiation counterpart at the outset of the negotiations (Conceição-Heldt 2011). During the negotiating process, parties use the size-of-concession tactic by making small concessions at different stages. From this perspective, disclosing too much information weakens a negotiator's bargaining power. This is because doing so limits what an actor has to offer in the final round of negotiations, making that actor vulnerable to exploitation by the counterpart. The EU's unilateral decision to disclose its initial negotiating texts to the public through its new TTIP website made this information automatically available to the USA as well. In order to explain how the bargaining leverage of the Commission has been affected by the EU's embrace of greater transparency, we briefly introduce the concepts of bargaining power and leverage.

Bargaining power is the ability of one party to influence its counterpart and thus obtain its preferred outcome in negotiations. Bargaining leverage comes from knowing one's counterparts' position or their true reservation line in a negotiating setting. This raises the question of whether opting for a partial transparency strategy gave the EU more or less bargaining leverage in TTIP negotiations. Since both negotiating partners have big markets to offer-with 500 million for the EU and 300 million consumers in the US case-negotiations took place in a symmetrical bargaining-power constellation. Negotiation theorists expect actors with a strong best alternative to a negotiated agreement to be less dependent on the opposing party in obtaining its preferred outcome than if it had a weak alternative or no alternative at all (Conceição-Heldt 2011, 2014; Odell 2000). Before starting with TTIP negotiations, both parties were individually negotiating free trade agreements (FTAs) at the regional and bilateral levels giving them similar bargaining power.

If the EU chooses a partial transparency approach in trade negotiations but its counterparts choose a low level of transparency, this can, from a bargaining perspective, have a twofold effect on its bargaining leverage. First, it can decrease this leverage because the other side can insist on pushing the reservation point further down the line. Partial transparency on only one side can also result in the asymmetric distribution of information. But partial transparency can increase the chances of the parties to reach a negotiated agreement. If the USA could anticipate what the EU's true reservation line was, it could then propose an agreement that fell within that winset, whilst maximizing its own gains. Second, a partial transparency approach could increase the EU's bargaining leverage. As we have known since Thomas Schelling's (1960) seminal study on the paradox of weakness, being in a position 
of weakness can be a source of bargaining power. The Commission can point to recalcitrant member states to extract more concessions from the other side and thus strengthen the EU's bargaining position (Putnam 1988). Stasavage considers posturing as the "incentive for representatives to adopt uncompromising positions during negotiations to demonstrate to their constituents that they are effective or committed bargainers" (Stasavage 2004: 673). Increased bargaining leverage can, however, have the unintended effect of diminishing the Commission's discretion during negotiations. In a situation of disunity and inability to send a single message to the Commission (Conceição-Heldt and Meunier 2014)—or when member states decide to interfere in the Commission's actions before, during and after negotiations-this might decrease the Commission's room for manoeuvre (Conceição-Heldt 2010, 2017). Finally, engaging in "tied-hands" bargaining strategies will succeed only if counterparts can be persuaded that the Commission is not bluffing. This brings us to the following proposition:

Partial transparency can weaken or strengthen the EU's bargaining leverage depending on the other side's approach to transparency and on the credibility of the tied-hands bargaining strategy.

\section{Effects of transparency on informalization}

Partial transparency can also transform the nature of the negotiation process by leading to the informalization of EU trade governance and paradoxically increasing contestation instead of muting it. With the recent turn in European and global governance towards more informal modes of decision-making (Christiansen and Neuhold 2014; Kleine 2013; Stone 2013; Vabulas and Snidal 2013), different conceptualizations of informal governance have arisen. Whereas Stone defines "informal power" as "the ability to obtain desirable outcomes within an organization (...) by going outside of normal channels" (Stone 2013: 125), for Christiansen and Neuhold informal governance includes, in addition to decisions taken place outside formal arrangements, the process or procedure by which policies are made and the outcome of any such informal process (Christiansen and Neuhold 2014: 4).

Following this distinction, the informalization of trade governance refers to a shift in the processes of decision-making from formal institutional structures towards informal and non-institutionalized settings. This raises the question of the conditions under which informal governance can be expected to develop. Informal institutions and practices give bargaining parties more flexibility to interact outside formal structures by establishing regular mini-meetings to discuss issues of common concern, to build consensus on controversial issues with the aim of finding a package deal acceptable to the constituencies of both sides (see also Vabulas and Snidal 2013).

Although the literature on informal governance in European and global governance is quite rich in mapping characteristics of informal governance, it tells us little about the consequences of informal governance on contestation. With regard to its impact on democracy, scholars have underlined that the loss of transparency inherent to informal arrangements might be normatively problematic because access to 
information in informal settings may be restricted, and informal governance may involve "unwritten rules" that are not publicly available. Due to its lack of transparency, informal governance can lead to more contestation. Public scrutiny and accountability are weakly developed because, in most cases, reliable information is not available about the locus of political power, the identity of involved actors, and the nature of decision-making procedures (Christiansen and Neuhold 2014). Grigorescu (2015: 10) underlines, however, that, depending on the quality of democratic procedures in European institutions, informal arrangements may effectively complement formal institutions, allowing for greater flexibility. If European institutions have well-developed transnational democratic features-including CSO access to European institutions, transparent decision-making processes, and the accountability of Commission officials to those affected by their actions-partial transparency is less likely to lead to more contestation. In the realm of EU institutional trade policy, citizens perceive the quality of democratic procedures as poor. Trade policy-making is viewed as a highly technical issue, compounded by the growth of regime complexes linking issues across a multitude of nested and overlapping institutions and agreements (Alter and Meunier 2009; Meunier and Morin 2015). Whilst the Commission has opened up to CSOs and business groups, it has to report to the Council and the European Parliament on the state of negotiations before, during and after negotiations. This means that adopting a partial transparency strategy can lead to more contestation if the impression develops that the Commission is conceding too much without getting any substantial concessions in return. This leads us to the following proposition:

Partial transparency can lead to more informal arrangements and increase contestation instead of silencing it, if the impression develops that the Commission is conceding too much.

The informalization of EU trade governance can also lead to divisions within the DG trade because some officials will be concerned rather with public contestation and others with EU bargaining. As a result, the first group are more likely to support greater transparency. For those involved directly in negotiations, by contrast, more transparency might produce new problems, such as information asymmetry and more public discussion. Informalizing trade governance offers a way out of this dilemma. Whilst this might improve the EU's bargaining leverage, it decreases transparency and might thus lead to a new spiral of protest or to new demands to move towards a full transparency approach.

\section{Three paradoxical findings}

The EU's decision to partially increase transparency had three crucial effects on TTIP negotiations. First, partial transparency paradoxically enhanced contestation instead of quieting it down. Second, partial transparency increased EU bargaining leverage but it led to low discretion for the Commission during negotiations. This is in line with findings of more recent studies on trade policy (De Bièvre 2018). Finally, partial transparency transformed the nature of the negotiating process by 
making it more informal, with decisions taking place outside formal institutional channels. This resulted in less transparency and less accountability, thus increasing contestation. I now turn to each one of these findings.

\section{Partial transparency increased contestation}

The first paradoxical consequence of greater transparency in TTIP negotiations was that it provoked more contestation. The launch of TTIP negotiations was followed by protests against their secrecy. For example, a coalition of $48 \mathrm{CSOs}$ submitted a European citizens' initiative to the Commission to stop TTIP in July 2014 (Agence Europe 2014a). Following this, the Council of Ministers decided to declassify the Commission's negotiating directives in October 2014 (Council of the European Union 2014). A second step to increase transparency was taken when the EU trade commissioner Malmström decided in November 2014 to publish some of the negotiating texts. She announced the public disclosure of EU negotiating proposals to which member states and MEPs from the International Trade Committee (INTA) already had access, gave all MEPs access to a reading room, and classified fewer TTIP negotiating texts as "restricted". These measures were designed to meet the demands of the new INTA chairman, Bernd Lange, who had requested more substantial access for MEPs (and the public) to the EU's negotiating texts (Agence Europe 2014b).

Between November 2014 and January 2015, the Commission disclosed all texts on the EU's negotiating position related to regulatory issues, such as public procurement and technical barriers to trade. Negotiating texts relating to market access issues, however, remained classified (Agence Europe 2015a). Opting for a partial transparency approach, in which negotiating texts on regulatory issues were made accessible but those on market access were not disclosed, triggered greater contestation from citizens and MEPs. The choice of a selective transparency approach with full transparency on market access but partial transparency on regulatory issues fuelled CSO contestation. A first reaction from 375 CSOs in March 2015 was to address an open letter to the EP demanding full transparency on all TTIP negotiating texts (Agence Europe 2015b). At the same time, CSOs asked for fuller inclusion in the negotiation process (Gheyle and De Ville 2017).

In past trade negotiations, the EU had usually opted for a low transparency strategy. Commission officials explain this Commission approach as "an efficient trade machine" in negotiating FTAs (Interview with Commission official \#12). The Commission has traditionally taken care of negotiations, providing periodic updates to member states on the progress made. Although the Commission and member states sometimes disagreed on the extent of concessions, at the end of the day, member states were able to accept FTAs and "sell" them to their citizens as a package. If there were clear losers in certain economic sectors, the Commission would assume the role of scapegoat (Interview with Council official \#12).

In the case of TTIP negotiations, the choice of a partial transparency approach backfired and increased contestation. However, this could only come about in conjunction with the high public salience of TTIP negotiations, in contrast to other EU 
trade agreement negotiations. On regulatory issues, the Commission chose to disclose its negotiating position, arguing there was less need for secrecy on these issues because there were no underlying trade-offs. On market access, the Commission did not disclose the EU position, as such issues are more sensitive and disclosure would make it more difficult to agree to concessions during negotiations. Some Commission officials considered partial transparency a "messy approach", as they did not know how long the Commission would be able to stick to it. Depending on the extent of contestation, they expected the trade commissioner to shift from partial towards full transparency to silence contestation (Interview with Commission officials \#12 and \#14). To be sure, the adoption of a selective transparency approach went back to a Council decision. Even though the Commission proposed and demanded that the Council make the negotiating mandate public, a qualified minority of member states refused to publish the mandate, opposing increasing transparency (see also De Bièvre and Poletti 2016; European Commission 2016) on the grounds that full transparency would decrease Commission discretion during negotiations (Interview with Council official \#12).

During negotiations, the Commission strengthened transparency at the national level to mitigate contestation. The College of Commissioners appointed three officials for Germany, France, and Austria tasked with answering questions citizens might have about TTIP in the hope of weakening contestation. These officials represented the Commission in national capitals, communicated the specifics of the EU negotiating position, and reinforced direct contact with citizens. However, Commission officials also acknowledged that this new strategy to reduce contestation had its limits. In general, journalists and the public preferred to interact directly with national high-ranked politicians, such as Germany's Chancellor Angela Merkel, and not with "technocrats" from Brussels (Interview with Commission official \#15).

\section{Greater transparency: more EU bargaining power but less Commission discretion}

The second paradoxical consequence of greater transparency was that it strengthened the EU's bargaining power, but decreased the Commission's range of discretion at the negotiating table. The official position of the Commission on transparency was to make the EU's negotiating mandate public on regulatory issues but not on market access issues (Interview with Commission officials \#14 and \#15). The Commission reported on a weekly basis to EU member state governments in the Council, in the TPC and the EP in the INTA. It also informed CSOs on the progress of negotiations. Apart from the initial negotiating directives from the Commission, further negotiating positions on market issues remained classified (Interview with Commission official \#12). Even though the Commission acknowledged that "a certain level of confidentiality is necessary to protect EU interests and to keep chances for a satisfactory outcome high" (European Commission 2015), the Commission disclosed $97 \%$ of negotiating texts (Interview with Commission official \#11).

This could have weakened the EU's bargaining power, as the USA had not made its positions public, opting instead for a full secrecy approach. The US ambassador to the EU Anthony Gardner argued that "We are in favour of transparency but other objectives also need to be taken into account. Total transparency can perhaps 
be an obstacle to a frank and honest dialogue" (Agence Europe 2014c). The new trade promotion authority (TPA) that the US Congress had adopted in June 2015 gave the US Trade representative (USTR) the power to negotiate FTAs that can only be accepted or rejected "as is" by Congress at the ratification stage. Although very extensive, the TPA bill only defines general objectives for FTAs and does not specify American reservation lines. This was very tricky for the EU, as the USA was also not as strongly engaged in the TTIP negotiations as the EU (Interview with Commission official \#11 and Council official \#12). Rather, the main priority of the USA was to conclude negotiations on the Trans-Pacific Partnership, as these markets were considered more attractive for the US business sector.

Commission officials involved in TTIP negotiations underlined that increasing transparency strengthened EU bargaining power, as it allowed the EU to better influence the US negotiating position. If, for example, the USA was not reacting to EU demands-for example, to include sustainable development issues in TTIP-sharing the EU position with US stakeholders would induce the latter to put pressure on the US administration to change its position, thus strengthening the EU's position. A second positive effect of partial transparency related to the EU negotiating position was that the USA knew the EU's negotiating position was genuine and could identify where EU sensitivities lay. This signalled to the USA that the Commission was not bluffing, thereby enhancing the credibility of the EU negotiating position (Interview with Commission official \#11). During TTIP negotiations, however, this strategy, did not lead to greater concessions from the USTR. One of the paradoxical effects of the domestic constraints strategy was that the low degree of discretion conferred on the Commission by member states led to strong involvement of different national actors during the negotiation process and to updating of the EU negotiating text due to opposition from some major member states and MEPs. For example, the Commission modified the text on the arbitration system, proposing a new Investment Court System, which included a Tribunal of First Instance and an Appeal Tribunal, both with publicly appointed judges (European Commission 2015), to obtain the support of German MEPs from the Alliance of Social Democrats.

Internally, greater transparency induced the Commission to set up a "reading room" in which member states and MEPs could consult classified negotiating texts without permission to speak in public about the content of these documents (Interview with Commission officials \#15 and \#16). This led members of the German parliament to ask for full disclosure of negotiating texts and fuelled contestation, as public opinion increasingly questioned the authority of the Commission. At the same time, paradoxically and probably due to the high level of technicity inherent in trade agreements texts, the interest in reading the texts was practically inexistent (Frankfurter Allegemeine Zeitung January 27, 2016). The Commission, however, did not shift from partial to full transparency. One reason might have been the opposition of some member states who argued that the Commission needed some room for manoeuvre on tariff rates when negotiating with the USA (Interview with Commission officials \#\#11 and \#14 and Council official \#12).

At the same time, Commission and Council officials emphasized that member states' representatives and MEPs had different preferences on access to information to decrease contestation. Member states were used to the Commission going into a 
"back room" to negotiate and coming out with an agreement, taking the blame for unpopular policies or outcomes. This has the advantage for member states that the Commission comes up with a package deal that is also easier to "sell" at the domestic level than when an issue-by-issue negotiating approach is taken (Interview with Commission official \#12).

Council officials also stated that member states needed time to adapt to this new context of partial transparency. Within the Council, member states were divided on the question of partial or full transparency. For example, a group of member states, including the Scandinavian countries, Germany, and France, opposed publication of the Commission's negotiating mandate with the argument that this would diminish the Commission's range of the discretion during negotiations. Member states agreed to decide on a case-by-case basis which negotiating directives could be disclosed (Interview with Council officials \#11 and \#12).

Within the Commission, officials were also divided on the effects of transparency on EU bargaining leverage. Some negotiators acknowledged that "transparency on all fronts" could backfire and have a negative effect on the EU's bargaining leverage because the more information the USA had on the EU negotiating position, the easier it would be for them to know where the reservation line of the EU was. In practice, however, EU bargaining leverage was not prejudiced, as EU negotiators disclosed only the initial negotiating text. However, the range of Commission discretion was reduced as some member states-notably Germany in the person of the Minister of Economy, Sigmar Gabriel-interfered in the negotiations by publicly complaining about the concessions offered by the Commission and even questioning continuation of the negotiations due to a lack of concessions from the USA (Interview with Commission officials \#11 and \#12 and Council official \#12). Even if this can be considered "posturing", signalling to domestic audiences that a country is a commited negotiator defending the trade interests of the EU and, in this case, Germany, this kind of interference reduces Commission discretion during negotiations.

\section{Transparency increased informalization}

The third paradoxical effect of the partial transparency approach was that, instead of increasing transparency, negotiations moved to the informal technical level, with Commission officials negotiating bilaterally with officials from the USTR and US Department of Trade in inter-personal, non-written communication. The new transparency approach implied that, if there was a request by stakeholders (e.g., business groups or CSOs) for access to emails from Commission officials related to TTIP, they could be disclosed. Consequently, emails had to be archived and Commission officials were therefore cautious when writing them. The consequence of the "transparency on all fronts" politics was, with some exceptions related to market access, that non-written settings became more important at the international and European levels. Discussions on issues at stake took place outside formal structures and in informal settings such as personal meetings or phone conferences to avoid generating written documents that would subsequently have to be released to the public and MEPs (Interview with Commission official \#12). 
At the EU level, the monitoring of negotiations included not only centralized oversight mechanisms at the TPC and INTA but also at the new Monitoring Group of the EP (Interview with Commission official \#11). On 25 September 2015, the INTA created a new Monitoring Group for the USA to follow the ongoing negotiations (Interview with EP official \#11). This group, composed of the INTA chair and members as well as the chairs and members of eleven other EP committees, met with the EU chief negotiator, Ignacio Garcia Bercero, once a month to discuss the agenda for the next round of TTIP negotiations. However, there was no formal rule on when and how regularly MEPs should meet with EU negotiators (Interview with Commission officials \#15 and \#16). In addition, there were secret inter-ministerial meetings between the DG Trade and US trade officials of which no minutes were disclosed. The increase in partial transparency during the negotiations led EU and US trade officials to negotiate in informal settings, thus paradoxically diminishing transparency. This shift of negotiations to informality allowed negotiators to deliberate without public contestation and decide what information on informal meetings would be disclosed to the public. This resulted in more contestation and confirmed protesters' arguments about secrecy and limited accountability. The EP and some CSOs protested virulently against this move towards negotiating outside formal channels and used it as a "casus belli" (Interview with Commission official \# 12) against the Commission. In the absence of a pro free trade centre-right majority, MEPs from the leftist, extreme-right, and anti-EU parties allied with CSOs to mobilize publicly against TTIP. A toxic combination of anti-Americanism, anti-globalization, and free trade was exploited politically to increase contestation against TTIP (Interview with Commission officials \#12, \#15 and Council Official \#14).

\section{Conclusion}

In this piece, we have argued that the partial increase in transparency has had three paradoxical effects on TTIP negotiations. First, greater transparency has enhanced contestation instead of quieting it down. Whilst partial transparency allowed the Commission to decide what information was released, it did not decrease public protest. The strategy backfired because the disclosure of partial information revealed to the public that part of the information was still classified and that there were specific negotiating texts the Commission was not willing to share with the public due to opposition from some member states. As a result, protest actually increased because the measures fed a sense of secrecy instead of muting it. Second, greater transparency increased the EU's bargaining leverage, as the Commission could argue that disunity within the Council together with public opinion and pressure from CSOs hindered further concessions. However, it also reduced the Commission's range of discretion due to interference from some member states during negotiations. Finally, the partial transparency approach informalized EU trade governance, allowing both sides to act outside public scrutiny, but unexpectedly increased public contestation by MEPs and CSOs.

One consequence of greater transparency is that TTIP has been labelled the most transparent trade negotiation in EU history (Coremans 2017). Following the 
highly contested TTIP negotiations, a second consequence was the decision by the European trade commissioner after the breakdown of negotiations to shift to full transparency by making all trade negotiating texts publicly available for future trade agreements in order to avoid new waves of contestation. However, there were also downsides to the politicization of TTIP negotiations. First of all, negotiations failed and it is less likely that a transatlantic trade agreement will be revived under the current US trade administration. Second, the contestation of TTIP negotiations politicized the role of the Commission and called its authority as EU trade negotiator into question.

As a result of increasing transparency in trade negotiations, the negotiation of trade agreements has now entered a new era in which conducting negotiations behind closed doors prompts great rumblings of discontent at all levels. The EU will have to learn to strike a balance between the transparency and efficiency of negotiations, as transparency increases perceptions of inclusion but undermines efficiency. Greater transparency not only shaped TTIP negotiations, it has also affected trade governance more generally, with Commission officials and the trade commissioner using social media, including Twitter, to communicate with the public. For the first time, TTIP also enormously politicized this policy area, increasing public awareness of trade agreements and of the Commission's central role and power. Politicization, together with the inclusion of the Parliament formally at the ratification stage and informally during negotiations, has led to an increase in Commission responsiveness and accountability towards the EP and European citizens. This finding is in line with other studies in this field, which expect the responsiveness of international organizations to increase as a consequence of politicization (Zürn 2014) and investigate how the Commission reacts to politicization in consumer policy (Rauh 2016).

Acknowledgements Earlier versions of this article have been presented to the Council for European Studies conference, 14-16 April 2016, Philadelphia and to the workshop "Transatlantic Trade and Investment Partnership", 14-15 March 2016, University of Gothenburg. I am particularly grateful to the following officials from the European Commission's Directorate General Trade and Council officials from the General Direction Trade, Development, Horizontal Issues and Foreign Affairs and from Trade Policy Committee (TPC) for their availability and willingness to share their knowledge with me: John Clarke, Luca De Carli, Ignacio Garcia-Bercero, Lutz Güllner, Bostja Krasovec, Alda Silveira Reis, and Ruta Zarnauskaite. For insightful comments on previous versions, I would like to thank the two anonymous reviewers, Andreas Dür, Patrick Mello, Guri Rosén, Henning Schmidtke, Mario Teló, Alasdair Young, and Jonathan Zeitlin. This project received generous funding from the European Union's Seventh Framework Programme for research, technological development and demonstration under ERC Grant Agreement No. 312368 .

Open Access This article is distributed under the terms of the Creative Commons Attribution 4.0 International License (http://creativecommons.org/licenses/by/4.0/), which permits unrestricted use, distribution, and reproduction in any medium, provided you give appropriate credit to the original author(s) and the source, provide a link to the Creative Commons license, and indicate if changes were made.

\section{References}

Agence Europe. 2014a. Citizens' Initiative to Stop TTIP Negotiations, July 17. Brussels. 
Agence Europe. 2014b. Four Actions for Greater Transparency of TTIP Negotiations, November 26. Brussels.

Agence Europe. 2014c. Ambassador Gardner Wants to Restore Trust, September 3. Brussels.

Agence Europe. 2015a. New Stage in European Initiative for TTIP Transparency, January 8. Brussels.

Agence Europe. 2015b. Deeply Rooted Distrust of TTIP in Civil Society, March 7. Brussels.

Aggarwal, V., and S.J. Evenett. 2016. The Politics of TTIP: Negotiating Behind the Border Barriers. In Schwerpunkt Außenwirtschaft, ed. E. Gnan and R.H. Kronberger, 191-214. Vienna: ultas Verlags- und Buchhandels AG facultas.

Alter, K., and S. Meunier. 2009. The Politics of International Regime Complexity. Perspectives on Politics 7(1): 13-24.

Bauer, M. 2016. Manufacturing Discontent: The Rise to Power of Anti-TTIP Groups. ECIPE Occasional Papers 02: 1-147.

Christiansen, T. and C. Neuhold (eds.). 2014. International Handbook on Informal Governance. Cheltenham: Edward Elgar.

Conceição-Heldt, E. 2010. 'Who Controls Whom? Dynamics of Power Delegation and Agency Losses in EU Trade Politics. JCMS: Journal of Common Market Studies 48(5): 1109-1126.

Conceição-Heldt, E. 2011. Negotiating Trade Liberalization at the WTO: Domestic Politics and Bargaining Dynamics. Basingstoke: Palgrave Macmillan.

Conceição-Heldt, E. 2014. When Speaking with a Single Voice Isn’t Enough: Bargaining Power (A) symmetry and EU External Effectiveness in Global Trade Governance. Journal of European Public Policy 21(7): 980-995.

Conceição-Heldt, E. 2017. Multiple Principals' preferences, Types of Control Mechanisms, and Agent's Discretion in Trade Negotiations. In The Principal Agent Model and the European Union, ed. Tom Delreux and Johan Adriaensen, 203-226.52. Basingstoke: Palgrave Macmillan.

Conceição-Heldt, Eugénia, and Sophie Meunier. 2014. Speaking with a Single Voice: Internal Cohesiveness and External Cohesiveness of the EU in Global Governance. Journal of European Public Policy 21(7): 961-979.

Coremans, E. 2017. From Access to Documents to Consumption of Information: The European Commission Transparency Policy for the TTIP Negotiations. Politics and Governance 5(3): 29-39.

Council of the European Union. 2014. Directives for the Negotiation on the Transatlantic Trade and Investment Partnership between the European Union and the United States of America. Brussels: Council of the European Union.

Czesana, R., and S. Meunier. 2018. 'From Back Rooms to the Street: Explaining the Gradual Publicization of Trade Policy-Making in Europe' Paper presented at the conference European Union Trade Policy in the 21st Century, Carleton University, Ottawa, March 9.

Damro, C. 2015. Competitive Interdependence and TTIP. EUSA EU Political Economy Interest Section 20: 5-8.

De Bièvre, D. 2018. The Paradox of Weakness in European Trade Policy: Contestation and Resilience in CETA and TTIP. The International Spectator 53(3): 70-85.

De Bièvre, D., and A. Poletti. 2016. Why the Transatlantic Trade and Investment Partnership is not (so) new, and why it is also (not) so bad. Journal of European Public Policy 24(10): 1506-1521.

De Ville, F., and G. Siles-Brügge. 2016. TTIP: The Truth about the Transatlantic Trade and Investment Partnership. Chichester: Polity.

Dür, A. 2017. Virtual Special Issue: EU Trade Policy. Journal of European and Public Policy. http:// explore.tandfonline.com/content/pgas/rjpp-vsi-eu-trade-policy

Eliasson, L.J., and P. García-Duran. 2016. Why TTIP is an Unprecedented Geopolitical GameChanger, But Not a Polanyian Moment. Journal of European Public Policy 24(10): 1522-1533.

European Commission. 2015. Factsheet: Transparency in EU Trade Negotiations. Brussels: European Commission.

European Commission. 2016. 'Who will decide whether to go ahead with a final deal?', in 'Questions and answers about TTIP-Basics, Benefits, Concerns. Available at http://ec.europa.eu/trade/ policy/in-focus/ttip/about-ttip/questions-and-answers. Accessed Jan 2019.

Gheyle, N., and F. De Ville. 2017. How Much Is Enough? Explaining the Continuous Transparency Conflict in TTIP. Politics and Governance 5(3): 16-28.

Grigorescu, A. 2015. Democratic Intergovernmental Organizations? Normative Pressures and Decision-Making Rules. New York: Cambridge University Press.

Gronau, J., and H. Schmidtke. 2016. The Quest for Legitimacy in World Politics - International Institutions' Legitimation Strategies. Review of International Studies 42(3): 535-557. 
Habermas, J. 1995. Theorie des kommunikativen Handelns. Band 1. Handlungsrationalität und gesellschaftliche Rationalisierung, Frankfurt (Main): Suhrkamp Verlag, kommunikatives Handeln Band 1.

Hamilton, D.S. and J. Pelkmans (eds.). 2015. Rule-Makers or Rule-Takers? Exploring the Transatlantic Trade and Investment Partnership. London: Rowman and Littlefield International.

Hooghe, L., and G. Marks. 2009. A Postfunctionalist Theory of European Integration: From Permissive Consensus to Constraining Dissensus. British Journal of Political Science 39(1): 1-23.

Huet, Patricia G., and Leif J. Elliasson. 2017. Supporters' Responses to Contested Trade Negotiations: the European Commission's Rhetoric on the Transatlantic Trade and Investment Partnership. Cambridge Review of International Affairs 30(5-6): 489-506.

Hutter, S., E. Grande, and H. Kriesi. 2016. Politicizing Europe. Integration and Mass Politics. Cambridge: Cambridge University Press.

Jančić, D. 2017. TTIP and Executive-Legislative Relations in EU Trade Policy. West European Politics 40(1): 202-221.

Kleine, M. 2013. Informal Governance in the European Union: How Governments Make International Organizations Work. Ithaca, NY: Cornell University Press.

Kriesi, H. 2016. The Politicization of European Integration. JCMS Journal of Common Market Studies 54(S1): 32-47.

Lax, D., and J.K. Sebenius. 1986. The Manager as Negotiator: Bargaining for Cooperation and Competitive Gain. New York: Free Press.

McCarthy, D.R., and M. Fluck. 2016. The Concept of Transparency in International Relations: Towards a Critical Approach. European Journal of International Relations. https://doi. org/10.1177/1354066116651688.

Meunier, S. 2003. Trade Policy and Political Legitimacy in the European Union. Comparative European Politics 1(1): 67-90.

Meunier, S. 2005. Trading Voices: The European Union in International Commercial Negotiations. Princeton: Princeton University Press.

Meunier, Sophie, and Jean-Frédéric Morin. 2015. No Agreement is an Island: Negotiating TTIP in a Dense Regime Complex. In The Politics of Transatlantic Trade Negotiations: TTIP in a Globalized World, ed. Jean Frédéric Morin, Tereza Novotná, Frederik Ponjaert, and Mario Teló, 196-209. Ashgate.

Meunier, S., and K. Nicolaïdis. 2006. The European Union as a Conflicted Trade Power. Journal of European Public Policy 13(6): 906-925.

Morin, J.-F., T. Novotná, F. Ponjaert, and M. Telò (eds.). 2015. The Politics of Transatlantic Trade Negotiations: TTIP in a Globalized World. Farnham: Ashgate.

Morse, J.C., and R.O. Keohane. 2014. Contested Multilateralism. The Review of International Organizations 9(4): 385-412.

Odell, J. 2000. Negotiating the World Economy. Ithaca: Cornell University Press.

Putnam, R.D. 1988. Diplomacy and Domestic Politics: The Logic of Two-Level Games. International Organization 42(3): 427-460.

Raiffa, H., J. Richardson, and D. Metcalfe. 2002. Negotiation Analysis: The Science and Art of Collaborative Decision Making. Cambridge, MA: Belknap Press of Harvard University Press.

Rauh, C. 2016. A Responsive Technocracy? EU Politicisation and the Consumer Policies of the European Commission. Colchester: ECPR Press.

Schelling, T. 1960. The Strategy of Conflict. Cambridge, MA: Harvard University Press.

Smith, M. 2015. The Meanings of TTIP: Reflecting on the Perils and Promises of Transatlantic Negotiations. EUSA EU Political Economy Interest Section 20: 18-21.

Stasavage, David. 2004. Open-Door or Closed-Door? Transparency in Domestic and International Bargaining. International Organization 58(4): 667-703.

Stone, R.W. 2013. Informal Governance in International Organizations: Introduction to the Special Issue. Review of International Organizations 8(3): 121-136.

Tallberg, J., T. Sommerer, T. Squatrito, and C. Jönsson. 2013. Opening Up: International Organizations and Transnational Actors. Cambridge: Cambridge University Press.

Tallberg, J. 2016. Transparency. In The Oxford Handbook of International Organizations, ed. J.K. Cogan, I. Hurd, and I. Johnstone, 1170-1192. Oxford: Oxford University Press.

Teló, M. 2015. Transatlantic Partnership and Global Governance from the EU's Perspective. In The Politics of Transatlantic Trade Negotiations: TTIP in a Globalized World, ed. J.-F. Morin, T. Novotná, F. Ponjaert, and M. Telò, 27-42. Franham: Ashgate. 
Vabulas, F., and D. Snidal. 2013. Organization without Delegation: Informal Intergovernmental Organizations. Review of International Organizations 8(2): 193-220.

Young, A. 2015. Liberalizing Trade, not Exporting Rules: the Limits to Regulatory Co-ordination in the EU's "New Generation" Preferential Trade Agreements. Journal of European Public Policy 22(9): 1253-1275.

Young, A. 2016. Not Your Parents. Trade Politics: The Transatlantic Trade and Investment Partnership Negotiations ', Review of International Political Economy 23(3): 345-378.

Young, A. 2017. The Politics of Deep Integration. Cambridge Review of International Affairs 30(56): 453-463.

Zürn, M. 2014. The Politicization of World Politics and its Effects: Eight Propositions. European Political Science Review 6(1): 47-71.

Publisher's Note Springer Nature remains neutral with regard to jurisdictional claims in published maps and institutional affiliations.

Eugénia C. Heldt holds the chair of European and Global Governance and is the founding dean of the School of Governance at the Technical University of Munich, Germany. She leads and conducts research about international organizations, multilateral governance, European Union, and accountability in global governance. She is the author of Negotiating Trade Liberalization in the WTO: Domestic Politics and Bargaining Dynamics (2011). Moreover, she has published many articles on the European Union, negotiation analysis, and global economic governance in journals such as Global Governance, Journal of Common Market Studies, Journal of European Public Policy, and Review of International Political Economy. 